\title{
Scenarios of the TWRS Low-Level Waste Disposal Program
}

Performance Assessment Team

Date Published

October 1994

Prepared for the U.S. Department of Energy Office of Environmental Restoration and Waste Management

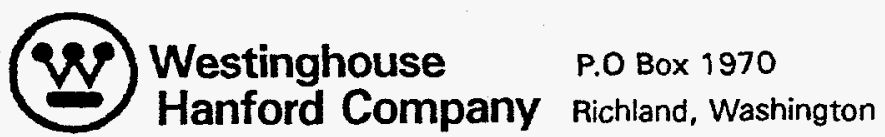

Hanford Operations and Engineering Contractor for the

U.S. Department of Energy under Contract DE-AC06-87RL10930 


\section{DISCLAIMER}

This report was prepared as an account of work sponsored by an agency of the United States Government. Neither the United States Government nor any agency thereof, nor any of their employees, make any warranty, express or implied, or assumes any legal liability or responsibility for the accuracy, completeness, or usefulness of any information, apparatus, product, or process disclosed, or represents that its use would not infringe privately owned rights. Reference herein to any specific commercial product, process, or service by trade name, trademark, manufacturer, or otherwise does not necessarily constitute or imply its endorsement, recommendation, or favoring by the United States Government or any agency thereof. The views and opinions of authors expressed herein do not necessarily state or reflect those of the United States Government or any agency thereof. 


\section{DISCLAIMER}

Portions of this document may be illegible in electronic image products. Images are produced from the best available original document. 
This is a preliminary working draft. It is expected to change and is intended to be used primarily to maximize public discussion and comment.

\title{
SCENARIOS \\ of the
}

TWRS LOW LEVEL WASTE DISPOSAL PROGRAM

\author{
Performance Assessment Team \\ October 13, 1994
}


WHC-EP-0828

Working Draft - Provided for Discussion Purposes Only

Table of Contents

1.0 OVERVIEW . . . . . . . . . . . . . . . . . . . 1

2.0 INTRODUCTION . . . . . . . . . . . . . . . . . . . . . . 1

3.0 FUtURE LAND USE ............................ . . . . 2

4.0 LAND USE-DRIVEN SCENARIOS . . . . . . . . . . . . . . 5

4.1 OVERVIEW . . . . . . . . . . . . . . . . . . . . 5

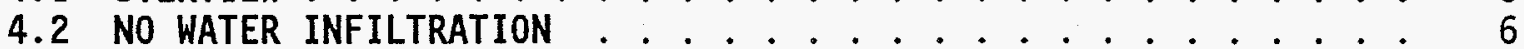

4.3 LOW WATER INFILTRATION RATE . . . . . . . . . . . . . . . . . 7

4.4 HIGH WATER INFILTRATION RATE . . . . . . . . . . . . . . . . 8

5.0 INADVERTENT INTRUDER SCENARIOS . . . . . . . . . . . . . . . 9

5.1 OVERVIEW . . . . . . . . . . . . . . . . . . . . . . . . . . . 9

5.2 HIGH WATER-INFILTRATION RATE INTO DISPOSAL SITE . . . . . . . 9

5.3 EXCAVATING INTRUDER . . . . . . . . . . . . . . . . . . . 10

5.4 WELL DRILLING INTRUDER . . . . . . . . . . . . . . . . . . . . . . 10

5.5 POST-INTRUSION RESIDENT . . . . . . . . . . . . . . . . . 11

6.0 NATURAL EVENT SCENARIOS ..................... 11

7.0 COMPARISON WITH OTHER PERFORMANCE ASSESSMENTS . . . . . . . . . . 11

7.1 GROUTED DOUBLE-SHELL TANK WASTE . . . . . . . . . . . . . . . . . 12

7.2 LOW LEVEL WASTE IN THE 218-W-5 BURIAL GROUND . . . . . . . . . . 12

7.3 SAVANNAH RIVER Z-AREA SALTSTONE . . . . . . . . . . . . . . 12

7.4 SAVANNAH RIVER E-AREA SALTSTONE . . . . . . . . . . . . . . . 13

7.5 OAK RIDGE SWSA 6 AREA . . . . . . . . . . . . . . . . . . . 13

7.6 NEVADA TEST SITE ...................... 13

7.7 IDAHO RWMC ......................... . . . 14

Table I. Summary of Scenarios for the TWRS LLW PA . . . . . . . . 15 
WHC-EP-0828

Working Draft - Provided for Discussion Purposes Only

\subsection{OVERVIEW}

The scenarios used to judge the performance objectives of this performance assessment are based upon past performance assessments and public input. The scenarios assume different future uses of the area containing the disposal facility as well as future potential regional events. Presently, the disposal facility is planned for the Central Plateau, a large raised area near the center of the Hanford Reservation. Table I presents the scenarios proposed for use in this performance assessment.

\subsection{INTRODUCTION}

As a result of past Department of Energy (DOE) weapons material production operations, Hanford now stores nuclear waste from processing facilities in underground tanks on the 200 area plateau. An agreement between the DOE, the Environmental Protection Agency (EPA), and the Washington state Department of Ecology (the Tri-Party Agreement, or TPA) establishes an enforceable schedule and a technical framework for recovering, processing, solidifying, and disposing of the Hanford tank wastes.

The present $p$ lan includes retrieving the tank waste, pre-treating the waste to separate into low level and high level streams, and converting both streams to a glass waste form. The low level glass will represent by far the largest volume and lowest quantity of radioactivity (i.e., large volume of waste chemicals) of waste requiring disposal. The low level glass waste will be retrievably stored in sub-surface disposal vaults for several decades. If the low level disposal system proves to be acceptable, the disposal site will be closed with the low level waste in place. If, however, at some time the disposal system is found to be unacceptable, then the waste can be retrieved and dealt with in some other manner. WHC is planning to emplace the waste so that it is retrievable for up to 50 years after completion of the tank waste processing.

Acceptability of disposal of the TWRS low level waste at Hanford depends on technical, cultural, and political considerations. The Performance Assessment is a major part of determining whether the proposed disposal action is technically defensible. A Performance Assessment estimates the possible future impact to humans and the environment for thousands of years into the future. In accordance with the TPA technical strategy, WHC $\mathrm{pl}$ ans to design a near-surface facility suitable for disposal of the glass waste. 


\section{Working Draft - Provided for Discussion Purposes Only}

One of the important initial steps in doing a performance assessment is to determine the scenarios to be used in determining the technical defensibility. For performance assessment activities, scenarios are the events and human actions that affect how the disposal action could interact with people and with the environment. A series of such events and actions which are thought to be likely and to provide a representative sample of possible future events are selected for analysis in the performance assessment.

Both public input and past performance assessments were reviewed to determine possible scenarios. The main factor driving these scenarios is land use.

\subsection{FUTURE LAND USE}

In 1992 the Hanford Future Site Uses Working Group was charged to determine potential future uses of various parts of the Hanford Site. This group consisted of local, state, and federal officials, representatives of affected Indian tribes, people from agriculture and labor, as well as members of environmental and special interest groups. Their summary report ${ }^{1}$ states

"Waste from throughout the Hanford Site should be concentrated in the 200 Area" [that is, the Central Plateau], and

"In general, the Working Group desires that the overall cleanup criteria for the Central Plateau should enable general usage of the land and groundwater for other than waste management activities in the horizon of 100 years from the decommissioning of waste management facilities and closure of waste disposal areas. For the foreseeable future, the Working Group developed six future options. These options distinguish different types of waste and different types of waste management which could occur in the Central Plateau."

The Future for Hanford: Uses and Cleanup: Summary of the Final Report of the Hanford Future Site Uses Working Group, December, 1992. The quotes are on pages 23 and 25 , respectively. Copies of the summary and of the full report (same date) can be obtained from Westinghouse Hanford Company, Richland, Washington. 


\section{WHC-EP-0828 \\ Working Draft - Provided for Discussion Purposes Only}

A11 six options involve the disposal of Hanford on-site waste into the Central Plateau. The various options differ regarding whether other waste (off-site Department of Energy [DOE] waste, commercial waste) should also be treated or disposed and whether compatible commercial or industrial activity would be allowed.

The reports notes

"The views of the Working Group members on any of these options are often held deep7y and they are diverse. Any future use option selected for the Central Plateau should be evaluated in light of all of the Working Group's findings and recommendations."

Those findings are

A. Hanford is important,

B. Cleanup is now DOE's primary mission at Hanford,

C. the Hanford site will change as cleanup proceeds,

D. both cleanup and future 7 and use face significant constraints,

E. Native American treaty rights exist,

F. uncertainty and risk surround the cleanup, and

G. time is a critical element in focusing the cleanup.

The recommendations were

A. Protect the Columbia River,

B. deal realistically and forcefully with groundwater contamination,

C. use the Central Plateau wisely for waste management,

D. do no harm during cleanup or with new development,

E. cleanup of areas of high future use value is important,

F. clean up to the level necessary to enable future use options to occur safely,

G. transport waste safely,

H. capture economic development opportunities locally, and

I. involve the public in future decisions about Hanford.

These principles will form the basis for the Hanford Remediation Action Environmental Impact Statement.

Thus, after a transition period (which would be short compared to the thousands of years of interest to this performance assessment), the area in and around the disposal area would be available for general use.

Four general land uses can be envisioned for the Central Plateau:

1. Industrial/commercial,

2. dry-land farming,

3. irrigated farming, and

4. natural. 
WHC-EP-0828

\section{Working Draft - Provided for Discussion Purposes Only}

Each 1 and use has different characteristics which will be important in developing scenarios for the performance assessment.

The present land use in the area is heavy industrial. If this use is maintained, it is highly likely that memory of past activities (particularly the disposal of nuclear materials) would be kept. In addition, knowledge concerning radioactivity should remain at least at current levels. Also, in an industrial area liquid discharges to the ground would likely be regulated and be kept small.

Southwest of the Hanford site lies the Horse Heaven Hills on which dry-land farming occurs. The Horse Heaven Hills are similar to the Central Plateau in the sense of being relatively near the Columbia River but at a significantly higher elevation than the river itself. Little irrigation occurs in the Horse Heaven Hills because of the relatively large energy cost (and hence economic cost) of bringing the water up to the surface. Ground water is used, however, for household and other small scale purposes.

East of the Central Plateau, across the Columbia River, irrigated area is extremely common. The water, however, does not come from the nearby stretches of the Columbia River, but from the Columbia Basin Project which derives its water from near the Grand Coulee Dam, over 200 miles upstream of Hanford. The water is gravity-fed to the farms. Because of the regional geography, such gravity feeding is much less likely for the Central Plateau.

Finally, west of Central Plateau is the Arid Lands Ecology reserve. This is a nature preserve area.

Outside of the Central Plateau, the Working Group sees mainly unrestricted use except to protect natural features (such as the Columbia River and nature preserves).

The results of the study group will be used as the basis for the Hanford Remedial Action Environmental Impact Statement (EIS). Future versions of this document will reflect the contents of this EIS. 
WHC-EP-0828

\section{Working Draft - Provided for Discussion Purposes Only}

\subsection{LAND USE-DRIVEN SCENARIOS}

\subsection{OVERVIEW}

The exposure scenarios described here assume that some controls remain in place to prevent public intrusion into the disposal areas. The barriers and markers which have been left are to be effective in preventing open use of the land over the disposal site.

For this performance assessment, the following scenarios are believed to provide an envelope around possible exposures:

1. No water infiltrating the disposal site (due to natural conditions). The only contaminants which are dispersed are gases and vapors which diffuse through the soil to the ground surface. Compliance points are reduced to just the air resource because no contamination reaches the water table.

2. Low water infiltration rate into the disposal site (because of industrial/commercial use, dry-land farming, or use as nature preserve). Both natural conditions and irrigated conditions outside of the Central Plateau will be assumed. Compliance points are:

a. (Public protection): water taken from a well 100 meters downstream from the edge of a disposal site and used by an individual for drinking water and to irrigate a small garden.

b. (ALARA): water is taken from the well and supplies a public drinking water system. The water supply is sized to provide maximum integrated dose. Another case is the total dose to about 5 million people living along the Columbia River between Hanford and the Pacific Ocean. [This latter case comes from other Hanford performance assessments with this disposal action as one of the contributors.]

c. (Ground water protection): groundwater leaving the disposal area is monitored at the well 100 meters downstream from the disposal site.

d. (Surface water protection): the point at which ground water enters the Columbia River.

e. (Air resource protection): bounded by Case 1 .

3. High water infiltration rate near the disposal site due to widespread irrigation. Irrigation is assumed outside of the Central Plateau as well. Compliance points are: 
Working Draft - Provided for Discussion Purposes Only

a. (Public protection): water taken from a well 100 meters downstream from the edge of a disposal site and used by in an individual for drinking water and to irrigate a subsistence farm on which the owner grows a portion of his vegetable and animal diet.

b. (ALARA): water is taken from the well and supplies public drinking water system. The water supply is sized to provide maximum integrated dose. Another case is the total dose to about 5 million people living along the Columbia River between Hanford and the Pacific Ocean.

c. (Ground water protection): groundwater leaving the disposal area is monitored at the well 100 meters downstream from the disposal site.

d. (Surface water protection): the point at which ground water enters the Columbia River.

e. (Air resource protection): bounded by case 1 .

\subsection{NO WATER INFILTRATION (CASE 1)}

1. The water infiltration rate at the disposal site is effectively zero due to the presence of an engineered barrier. The only contaminants which travel from the waste sites are gases and vapors which diffuse through the soil to the ground surface.

2. Resource Protection: there is no contamination of the ground water and therefore no contamination of the surface water. The only resource of interest for comparison with performance objectives is the air directly over the waste site.

3. Protection of the Public:

a. Resident: annual dose to a resident living directly over the disposal site is computed using the estimated air concentrations and any direct radiation from the buried waste form.

b. Surrounding Population: airborne emissions from the disposal site are carried in all directions to people nearby. However, such transport also dilutes the air concentrations. Experience has shown that if the individual living over the disposal site is protected, then the general public is also safe. 


\section{WHC-EP-0828 \\ Working Draft - Provided for Discussion Purposes Only}

\subsection{LOW WATER INFILTRATION RATE (CASE 2)}

1. The water infiltration rate at the disposal site remains similar to the natural infiltration rates at present. The land uses of the Central Plateau do not include large scale irrigation for commercial farming. Outside the Central Plateau there may be irrigated farming.

2. Air \& Water Resource Protection:

a. Ground water: water taken from a well 100 meters downstream from the edge of a disposal site will be compared with the performance objectives.

b. Surface water: water concentrations at locations where ground water enters the Columbia River will be compared with the performance objectives.

c. Ambient air: air concentrations over the disposal site are estimated from upward diffusion of gases and vapors. These concentrations are then compared with the performance objectives.

3. Protection of the Public:

a. Resident Gardener: water taken from a well 100 meters downstream from the edge of a disposal site is used by an individual for drinking water and to irrigate a small garden. The gardener obtains one fourth of the food he consumes annually from the garden. The resident gardener is exposed via direct consumption of well water, and the contamination which accumulates in his garden. The contaminated soil exposes the resident by three significant pathways:

i. contaminated dust which is inhaled and ingested,

ii. direct radiation exposure, and

iij. uptake into plants which are then eaten.

For most radionuclides, the direct consumption of well water gives most of the radiation dose.

b. Community We11: water from a we11 100 meters downstream from the edge of a disposal site supplies a small community with drinking water. The size of the community depends on how much water can reasonably be taken from the well for domestic uses.

c. Columbia River Population: water reaching the Columbia River mixes in the river and is carried downstream. The total dose to about 5 million people who may live between Hanford and the Pacific Ocean is estimated. Exposure pathways include direct consumption of the 
Working Draft - Provided for Discussion Purposes Only

water, fish taken from the River, and food crops and animal products raised using irrigation water from the Columbia River. The farming dose estimates include the accumulation of contaminants in animal products such as beef and milk in addition to the pathways used for the Resident Gardener.

\subsection{HIGH WATER INFILTRATION RATE (CASE 3)}

1. The water infiltration rate near the disposal site is much larger than natural infiltration due to widespread irrigation of the Central Plateau and other areas of the present Hanford Site. The higher infiltration rates affect groundwater concentrations and arrival times at the nearby well and the Columbia River.

2. Air \& Water Resource Protection:

a. Ground water: water taken from a well 100 meters downstream from the edge of a disposal site will be compared with the performance objectives.

b. Surface water: water concentrations at locations where ground water enters the Columbia River will be compared with the performance objectives.

c. Ambient air: air concentrations over the disposal site are estimated from upward diffusion of gases and vapors. These concentrations are then compared with the performance objectives.

3. Protection of the Public:

a. A11 Pathways Farmer: water taken from a we11 100 meters downstream from the edge of a disposal site is used by an individual for drinking water and to irrigate a farm. The farmer obtains a portion of the food he consumes annually from his farm. The all pathways farmer is exposed via direct consumption of well water, and the contamination which accumulates in the soil due to irrigation. The contaminated soil exposes the farmer by

i. contaminated dust which is inhaled and ingested, ii. direct radiation exposure, and

iii. uptake into plants and animals which are then eaten.

For most radionuclides, the direct consumption of well water still gives most of the radiation dose. 
WHC-EP-0828

\section{Working Draft - Provided for Discussion Purposes Only}

b. Community We11: water from a we11 100 meters downstream from the edge of a disposal site supplies a small community with drinking water. The size of the community depends on how much water can reasonably be taken from the well for domestic uses.

c. Columbia River Population: water reaching the Columbia River mixes in the river and is carried downstream. The total dose to about 5 million people who may live between Hanford and the Pacific Ocean is estimated. Exposure pathways include direct consumption of the water, fish taken from the River, and food crops and animal products raised using irrigation water from the Columbia River.

\subsection{INADVERTENT INTRUDER SCENARIOS}

\subsection{OVERVIEW}

The exposure scenarios described here assume that no memory of the disposal site remains. The barriers and markers are ignored.

The two principal classes of intruders are described below.

1. The disposal facility cover may be compromised by commercial farming activities. The increased water infiltration through the waste greatly increases the aquifer concentrations and reduces the travel time to a nearby well.

2. The inadvertent intruder digs into the disposal site and brings some of the waste to the surface where it can be spread around, resuspended, and expose individuals. The three inadvertent intruder scenarios usually considered in performance assessments are
a. Excavation for a basement or building foundation,
b. drilling for ground water or minerals, and
c. living where waste has been exhumed and spread around the surface.

\subsection{HIGH WATER-INFILTRATION RATE INTO DISPOSAL SITE}

1. The water-infiltration rate at the disposal site is much larger than natural infiltration due to widespread irrigation of the Central Plateau and other areas of the present Hanford Site. The higher infiltration rates affect groundwater concentrations and arrival times at the nearby we11, 100 meters downstream from the edge of the disposal site. 
Working Draft - Provided for Discussion Purposes Only

2. Water taken from a well 100 meters downstream from the edge of the disposal site is used by the intruder for drinking water and to irrigate his farm. The farmer obtains a portion of the food he consumes annually from his farm. The all pathways farmer is exposed via direct consumption of well water, and the contamination which accumulates in the soil due to irrigation. The contaminated soil exposes the farmer by

a. Contaminated dust which is inhaled and ingested,

b. direct radiation exposure, and

c. uptake into plants and animals which are then eaten.

For most radionuclides, the direct consumption of wel1 water still gives most of the radiation dose.

\subsection{EXCAVATING INTRUDER}

1. The excavator uncovers the disposal site and brings a large quantity of waste to the surface. The motivation for the earth moving activity is the need for a foundation or basement for a building.

2. Most of the radiation dose is received by the individuals doing the excavation. Exposure pathways include direct radiation from the buried waste as we 71 as what has been exhumed, and inhalation and ingestion of resuspended dust.

3. The excavator leaves the site when the excavation is complete. The exposure time is assumed to be less than two weeks.

\subsection{WELL DRILLING INTRUDER}

1. A well is drilled through the disposal site and brings a small quantity of waste to the surface. The motivation for the well drilling activity is the need for water or some mineral.

2. Most of the radiation dose is received by the individuals doing the excavation. Exposure pathways include direct radiation from the buried waste as we11 as what has been exhumed, and inhalation and ingestion of resuspended dust.

3. The drilling party leaves the site when the hole is complete. The exposure time is assumed to be one week. 
WHC-EP-0828

\section{Working Draft - Provided for Discussion Purposes Only}

\subsection{POST-INTRUSION RESIDENT}

1. An individual estabijshes a residence at the site of the intrusion (excavation or well drilling). The individual has a garden, but his water supply is free from contamination.

2. External exposure is received from both the exhumed waste as well as the original, undisturbed waste.

3. Internal exposure occurs as a result of the inhalation of airborne dust, the ingestion of crops grown in soil containing the exhumed waste, and ingestion of small amounts of soil directly.

\subsection{NATURAL EVENT SCENARIOS}

The main natural events to be expected are

1. Erosion of surface above disposal unit due to wind,

2. earthquakes, and

3. flooding due to post-glacial events.

The first two types of events are considered as drivers for changes in the engineered structure as a function of time.

The last event, which removes 30 or more meters of ground (including the disposal units), has occurred numerous times during the past 50,000 years of Hanford geologic history. In this scenario, the waste is uniformly deposited over the lower Columbia Basin.

The likelihood and consequences of the possible natural events are evaluated for the various land use scenarios which may be projected for the Central Plateau.

\subsection{COMPARISON WITH OTHER PERFORMANCE ASSESSMENTS}

Two other performance assessments (Grouted Double-She11 Tank Waste and the 218-W-5 Burial Ground) have been completed for the Hanford Site. The scenarios assumed for these two performance assessments are included in the present assessment. There are a few differences in the scope of the evaluations. There are larger differences with non-Hanford performance assessments because of different conditions at those sites. 
WHC-EP-0828

Working Draft - Provided for Discussion Purposes Only

\subsection{GROUTED DOUBLE-SHELL TANK WASTE (GROUT PERFORMANCE ASSESSMENT) ${ }^{2}$}

1. All exposure scenarios for the Grout Performance Assessment are included in the present assessment.

2. Additional analysis will be provided in this analysis to evaluate the non-intrusion scenarios against the air and water resource performance objectives.

\subsection{LOW LEVEL WASTE IN THE 218-W-5 BURIAL GROUND (SWPA) ${ }^{3}$}

1. A11 exposure scenarios for the SWPA are included in the present performance assessment. The intrusion by means of irrigation follows the discussion in the SWPA.

2. The community well scenario will be included in the present performance assessment.

\subsection{SAVANNAH RIVER Z-AREA SALTSTONE ${ }^{4}$}

1. The main exposure scenario is through ground water to a well located 100 meters downstream which is used for domestic purposes. Air-borne transport is also considered.

2. The intruder scenarios are similar to those used here except no irrigation scenario is used in the Savannah River analyses.

3. Except for earthquakes which are indirectly treated, no natural events are considered.

C.T. Kincaid, J.A. Voogd, J.W. Shade, J.H. Westsik, Jr, G.A. Whyatt, M.D. Freshley, M.G. Piepho, K.A. Blanchard, K. Rhoads, and B.G. Lauzon, Performance Assessment of the Grouted Double She 11 Tank Waste Disposal at Hanford, WHC-SD-WM-EE-004, Rev. 0, Westinghouse Hanford Company, Richland, Washington, October, 1993.

M.I. Wood, R. Khaleel, P.D. Rittman, A.H. LU, S. Finfrock, R.J. Serne, and K.J. Cantre11, Performance Assessment for the Disposal of Low-Level Waste in the 200 West Area Burial Grounds, WHC-EP-0645 (Draft), Westinghouse Hanford Company, Richland, Washington, May 6, 1994,

Radiological Performance Assessment for the Z-Area Saltstone Disposal Facility, WSRC-RP-92-1360, Westinghouse Savannah River Company, Aiken, South Carolina, December 10, 1992. 
WHC-EP-0828

Working Draft - Provided for Discussion Purposes 0nly

\subsection{SAVANNAH RIVER E-AREA SALTSTONE ${ }^{5}$}

The same analysis was performed as was done for the Z-Area.

\subsection{OAK RIDGE SWSA 6 AREA $^{6}$}

1. The main exposure pathway is from drinking water from a well 1ocated 100 meters downstream. Neither airborne transport nor irrigation were considered.

2. The intruder scenarios are similar to those used in this assessment except no irrigation scenario was considered.

\subsection{NEVADA TEST SITE ${ }^{7}$}

1. The main pathways were via air or via groundwater. The point of compliance was 100 meters from the disposal facility.

2. A more limited set of intruder scenarios was used than in the present analysis.

Radiological Performance Assessment for the E-Area Vaults Disposal Facility, WSRC-RP-94-218, Westinghouse Savannah River Company, Aiken, South Carolina, April 15, 1994.

Performance Assessment for Continuing and Future Operations at Sol id Waste Storage Area 6, ORNL-6783, Oak Ridge National Laboratory, Martin Marietta Energy Systems, Inc., Oak Ridge, Tennessee, February, 1994.

S.C. Magnuson, S.J. Maheras, H.D. Nguyen, A.S. Rood, J. Sing, et al, Radioactive Performance Assessment for the Area 5 Radioactive Waste Management Site at the Nevada Test Site, Idaho National Engineering Laboratory, EG\&G Idaho, Idaho Falls, Idaho, Revision 1. 
WHC-EP-0828

\section{Working Draft - Provided for Discussion Purposes Only}

\subsection{IDAHO RWMC ${ }^{8}$}

1. During the period of institutional control, the all-pathways receptor is at the INEL site boundary. Afterwards, the receptor is 100 meters from the disposal area boundary.

2. Air protection considered only the Radioactive Waste Management Complex and the receptor was $100 \mathrm{~m}$ from the disposal site boundary.

3. Inadvertent intruder included direct exposure, drinking groundwater, and radon doses.

4. Groundwater protection was derived from a well at the INEL site boundary $5.5 \mathrm{~km}$ from the RWMC.

8 Steven J. Maheras, Arthur S. Rood, Swen O. Magnuson, Mary E. Sussman, and Rajiv N. Bhatt, Radioactive Waste Management Complex Low-Level Waste Radiological Performance Assessment, EGG-WM-8773, Idaho National Engineering Laboratory, EG\&G, Inc., Idaho Falls, Idaho, May, 1994. 
WHC-EP-0828

Working Draft - Provided for Discussion Purposes Only

Table I. Summary of Scenarios for the TWRS LLW PA

Land Use Scenarios:

\begin{tabular}{|c||c|c|c|c|c|c|c||}
\hline \multicolumn{1}{|c|}{$\begin{array}{c}\text { Infi1- } \\
\text { tration }\end{array}$} & \multicolumn{3}{|c|}{ Resource Protection } & \multicolumn{4}{c|}{ Protection of the Public } \\
\cline { 2 - 8 } & Air & $\begin{array}{c}\text { Surface } \\
\text { Water }\end{array}$ & $\begin{array}{c}\text { Ground } \\
\text { Water }\end{array}$ & $\begin{array}{c}\text { Resi- } \\
\text { dent }\end{array}$ & Farmer & $\begin{array}{c}\text { Comm. } \\
\text { We11 }\end{array}$ & $\begin{array}{c}\text { River } \\
\text { Pop. }\end{array}$ \\
\hline None & $X$ & & & $X$ & & & \\
\hline Low & $X$ & $X$ & $X$ & $X$ & $X$ & $X$ & $X$ \\
\hline High & $X$ & $X$ & $X$ & $X$ & $X$ & $X$ & $X$ \\
\hline
\end{tabular}

Inadvertent Intruders:

\begin{tabular}{|c||}
\hline High Infiltration due to Irrigation On Disposal Site \\
\hline Drilling Through or Excavation Into Waste \\
\hline Resident Living on Waste Exhumed by Drilling or Excavation \\
\hline
\end{tabular}

Natural Events:

\begin{tabular}{|c|}
\hline Erosion of Waste Cover \\
\hline Seismic Event Compromising Waste Cover \\
\hline Major Flooding of Central Plateau \\
\hline
\end{tabular}

The Inadvertent Intruders are only evaluated against the intruder performance standard. The likelihood and consequences of Natural Events are evaluated for the various Land Use Scenarios. 
WHC-EP-0828

Rev. 0

DISTRIBUTION

Number of copies

ONSITE

13
F. M. Mann (10)

WHC Central Files

OSTI (2)
HO-35

L8-04

L8-07

Distr-1 


\section{RELEASE AUTHORIZATION}

Document Number: WHC-EP-0828, Rev. 0

Document Title: Scenarios of the Low-Level Waste Disposal Program

Release Date: $\quad 11 / 10 / 94$

This document was reviewed following the procedures described in WHC-CM-3-4 and is:

APPROVED FOR PUBLIC RELEASE

WHC Information Release Administration Specialist:

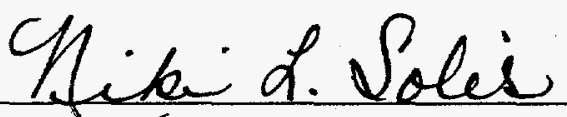

$11 / 10 / 94$

Niki L. Solis 